\title{
Study on Leadership Characteristics Model Based on Margaret Thatcher Review
}

\author{
He qiang, Wu mengying, Zhang miao \\ College of Management, Tianjin University of Traditional Chinese Medicine, Tianjin, China \\ heqiangmail@126.com
}

\begin{abstract}
This paper studies the characteristics list of leadership model based on the analysis Margaret Thatcher. Integrity, competitive spirit, passion and intuition, vision and adaptability, priority setting and decision making, influencing and persuading, all the factors constitutes the art of leadership.
\end{abstract}

Index Terms - Leadership, Margaret Thatcher, Characteristics

\section{Introduction}

Margaret Thatcher was marked by a series of "firsts." In June 1979, she became the United Kingdom's first female prime minister. In the twentieth century, she was the first prime minister who won three consecutive general elections (Gavin, 2009). She created Thatcherism, which is the famous and representative characteristic of her leadership. This essay will display five core competencies to analyze characteristics of Margaret Thatcher's leadership.

\section{Background}

Margaret Thatcher was born in a small family that ran a small grocery business. Her father, Alfred Roberts was interested in politics, which influenced Thatcher deeply (Gavin, 2009). Thatcher's father always told her "Insist on your own way and never run with the crowd." According to the early leadership theories, people believe a man should be a leader and hold the power. Women need stay at home and do housework. In addition, a prominent leader also needs strong family background, in that time. Margaret Thatcher broke those theories and became a legend in British history as well as in worldwide.

\section{Body}

\section{A. Integrity in Thatcher's leadership}

In this part, there are two main characteristics. The first one is ethical behavior. The second one is doing what one says (Gavin, 2009). For instance, she had less time than other children. Thatcher enjoyed studying and she did not like to go to shopping or some other things that casual girls loved. When Margaret Thatcher studied in Oxford, she was hard working. Thatcher preferred to read rather than play sport. She also used her spare time to studied Latin. Enthusiasm about her work, she said: "I never sleep more than four or five hours. Conversely, my life is my work, some artificial life and work, I live to work." When she became the prime minister, she spent more time to prepare her speeches. Margaret Thatcher never flinched in the face of challenges, more precisely. She was fearless. Paul Johnson, a political commentator said that even her strongest opponents admit she retains the real Churchill doctrine of courage." (Gavin, 2009)

In May 1979, Margaret Thatcher was elected as the British Prime Minister with 43.9 percent of the vote to a term of five years. Her holistic view was fresh and exciting to those who were to such a frank and candid leader (Gavin, 2009). A political biographer said "Her style is based on the manipulation of her colleagues. I have never seen a more confident, more impervious leadership, that is, to act the way she usually does. In 1975, she needed to establish a reliable stay at the helm of the team, she is in charge of each of the facts and data, she never even give up any claim, she was so annoying self-confidence. It seems that no one can put forward lurks in her decision-making unreliable factors (Gavin, 2009). Convinced that the degree of her final chips, the middle virtually non-existent voices of supporters and opponents. The party colleagues as "hopelessly middle class" women Finally, at the age of 53 to become the Prime Minister the indomitable personality she constantly set foot high political journey victories.

\section{B. Competitive Spirit}

Margaret Thatcher showed her competitive spirit her whole life. She never gave up. According to competition, she achieved her the peak of her career. She had incredible energy. Her classmates said: "I've never seen a human who has extreme spirit of strength and perseverance such as Margaret (Margaret Thatcher)." According to biographer Chris Ogdento, she is a typically excellent speaker. He said that when she delivered her first speech in the House, which was passionate, the lawmakers fell suddenly silent." In order to keep their competitive spirit and the concept of capitalism, Thatcher said: "Free competition gives the market more opportunities." Her biographer Bill Terry Murray (1980) said the West Asia conference clearly showed her indomitable and fearless spirit. She made a speech for the American television audience in December 1993. Thatcher said sleep four or five hours were good for health and sometimes she just slept half an hour. Margaret Thatcher was a real iron lady who had strength (Essential Margaret Thatcher, 2013).

\section{Passion and Intuition}

Margaret Thatcher was the first female prime minister, and she had passion and intuition. She had strength and enthusiasm for her work (Gavin, 2009). Thatcher had an extroverted and intuitive temperament, but also tended to the details. She preferred to use rational or thinking to solve the problem rather than use feelings or emotions. In addition, she had experience in scientific studies. Therefore, she had clear 
ideas and logic. She preferred to make the decision rather than wait for the result. Margaret Thatcher never evaded the issues even in a struggle.

Thatcher was stubborn and fearless. When Argentina seized the Falkland Islands, she took action (Miller, 1990). These islands are 8000 miles from the United Kingdom. Furthermore, the Falklands had only 1800 British citizens, 650,000 sheep and 10 million seagulls. For the most leaders, they believed Falkland Islands was no value and soldiers would die in vain.

Although Britain had fewer advantages than Argentina, the Prime Minister Margaret Thatcher made adequate preparation before the war. "Britain will stand on principle, or Britain will not stand at all." She made a decision to sink the Argentine ship General Belgrono. However, Argentina avenged this action. Meanwhile, President Regan and President Belaundo of Peru had some new proposals for the peace plan. Nevertheless, Margaret Thatcher told them there would be no appeasement for the Falklands (Miller, 1990). This was a war. It was a war Argentina started, and Britain would finish it. Thatcher believed that failure was impossible. The Falkland Islands were an inalienable part of Britain.

\section{Vision and Adaptability}

Thatcher liked the quote: "In competition, women are better than men." (Iorio, 2012) Many political leaders around the world believe she was the representation of this quote. Thatcher saved a precarious government. Thatcherism was her representative theory. She continued practical strategy to implement the philosophy of "Thatcherism." She sold a total of 30.6 billion pounds of British Telecom, British Airways, RollsRoyce Motor Company and many other state-owned enterprises stock, making them the shares of listed companies. Her government constructed one million units of public housing in the 1980s, which were in turn sold to residents so that British private home ownership increased from 52\% to 66\% (in 1988 only $63.9 \%$ of Americans had private houses). Thatcher controlled inflation, greatly weakening the terms of reference of the federal government to raise the economic growth rate to a level of more than a few decades ago (Essential Margaret Thatcher, 2013). There are some statistics can support that.

Thatcher, Mikhail Gorbachev and Ronald Reagan were friends. She was a world-famous national female leader. When she left in 1990, the venerable woman was one of the most influential forces in the world. She loved her career. Her father influenced her deeply. The education from her father, and role models in her 15 years at girls' school set a specific self-image. In university, she never compared with the boys at school and never desired for recognition from men (Myers, 1994).

Delivering on election promises in 1979, Margaret Thatcher guaranteed rate of inflation, weakened federal authority, and oversaw the creation of a new industry and trade system, rejuvenated economic prosperity, by the disintegration of the welfare state to change the social welfare system.

Margaret Thatcher's final summary of her autobiography: "all human achievements are on sand, our victory and our misfortunes are fleeting. We can not foresee the future, not to mention the decision future." She worked vigorously to limit the activities of the trade unions, to encourage the free market by repealing most of the benefits policy, tax relief (Myers, 1994). She said, the British people are freer, more prosperous, they own their own stock and more and more of their private property (Myers, 1994).

In November 28 1990, Margaret Thatcher resigned as prime minister and moved out of Downing Street. An individual who moved from an ordinary housewife to the country's highest office, and then returned to being a housewife.

\section{E. Priority Setting and Decision Making}

There are two key concepts of Thatcher's leadership in priority setting and decision-making.

The first one is you must be prepared for unexpected happen. The following is making the impossible happen is the art of leadership' $s$ art. For instance, Thatcher showed her leadership in Falklands' war. The Falkland conflict usually thought to represent Thatcher's characteristic of her leadership.

The Falkland War began on 2nd April 1982. The head of the Argentina, President Leopoldo Galtieri, authorized the invasion of the Falkland Islands. The operation was aimed at attracted attention away from the rights of human and economic issues. In addition, Argentina gave teeth to the national long-held legal right on the islands. On 2nd April, Argentina forces landed in the islands after an incident between Britain and Argentina. Prime minister Margaret Thatcher ordered the Assembly of a naval task force to retake the Falklands. The aircraft carriers "HMS Hermes" and "HMS Invincible" were the most notable aspect in the Falkland War. In middle April, Admiral Sir John Fieldhose began moving to south where is more than 8000 miles from British. Finally, the British stated the end of Falkland War on 14th June 1982.

Before Falkland War, Thatcher realized the disparity between the naval force and its enemies got wider. Although Britain did not have more advantages than Argentina, the Prime Minister Margaret Thatcher made adequate preparation before the war (Iorio, 2012). British will stand on principle, or British will not stand at all. She made a decision that was sinking the Argentina's General Belgrono. However, Argentina avenged this action. Thousands and tens of thousands of soldier died. Meanwhile, President Regan and President Belaundo of Peru had some new proposals for the peace plan. Nevertheless, Margaret Thatcher told them there was no appeasement for Falklands. This was a war. It was a war Argentina started British would finish it. According to this effective action and decisive decision, Britain won the war and victory boosted the national confidence as well as promoted British international position. In 1983, Thatcher government won the election, which was also the result of victory (Iorio, 2012).

Another example is the economy in Thatcher government. In 1979, Britain faced heavy economic problem such as strike. At the same year in Britain, Margaret Thatcher became Prime Minister. After a bit more than five years, Thatcher returned the conservatives to power once again. She willing to shared the sense of crisis felt by the public. She led to the Conservative Party a greater devotion to free market economics (Essential Margaret Thatcher, 2013). She insisted a school of 
economic concepts derived from two famous economists, Ludwig von Mises and Friedric von Hayek, Margaret Thatcher stood by mass freedom to reform over mandarine economic planning. She supported for letting capitalism work as little bit chained by governance as possible. Furthermore, Margaret Thatcher refused the point of view inflation could be resoundingly combated was more determined as President Ford had been. Thatcher believed that inflation unnerved saving and it supported short-term investing in markets by distributor rather than considerable investing in markets. She thought inflation reduced business.

\section{F. Influencing and Persuading}

In 1979, the British Conservative Party came to power, and Thatcher as the prime minister began a series of "radical" reforms in the field of education. She first abolished the Education Act enacted by the Labour government in 1976, resulting in the abolition of mandatory comprehensive reorganization. In 1979, the Conservative government took further action to stop integrated education movements and strengthen the independent schools (Barnes, 2005). The two Education Acts in 1980 and 1988 were the concrete manifestation of the concept of the Thatcher doctrine. The 1988 law gave primary and secondary schools which had more than 200 students independent power to decide how to use the financial resources provided by the local education authority.

It also provided that if the majority of parents in favor of, and the education minister agree, the public schools would be freed from the control of local education authorities, and thus become directly funded by the central government under the supervision of Direct Funding of Public Schools Act. All secondary schools could be eligible to apply for direct funding, but the application of primary school students required the school to have more than 300 students (Essential Margaret Thatcher, 2013).

Second, the law allowed public schools to implement local management. Under the provisions of the Act of 1988, $85 \%$ of the budget of the local education authority flowed directly into schools, and the school could make a decision about how to use the funding (Barnes, 2005). In addition, she required all local education authorities in various personnel management authority to the school. This requirement for all secondary schools and the number of students in more than two hundred primary school is compulsory.

Thatcherism under the guidance of the education reform in 1987, a group of of rightist teachers and scholars, Hill Gheit Group, in its report entitled "Whose School?" claimed parents lost faith with public education United Kingdom. The reason was that the local education authorities held the monopoly (Essential Margaret Thatcher, 2013).

In the 1970s, in the United Kingdom, the small business and independent business groups were popular. However, these groups were struggling in the difficult economy due to giant monopolies. Increasingly concentrated economic power of the giant companies brought a series of economic and socially adverse consequences. These caused small business communities to seize the opportunity to seek the support from the government and the banks while emphasizing consciously cultivated skills in school (Barnes, 2005). The government would naturally not to ignore their demands. In the 1980s, while education funding was cut, the universities and colleges opened a lot of business courses, Business School also sprung up.

The right-wing government, after a concerted effort, had allowed education and commercial to have a more close relationship. According to purchasing power parity, the UK's share of world GDP reduced from 4.3 percent to 4.1 percent between 1979 and 1990. In the next two years, it then dropped to around 3.6 percent, greatly thanks to the overvaluation of the pound due to its link to the deutschemark. Nevertheless, Britain's continued strength of economy is great to Margaret Thatcher. She was an inspiration to her heres, and demonstrated that free-market economic policies settle the path to improving living standards (Hutchinson, 2013).

\section{Conclusions}

In conclusion, Margaret Thatcher was a great leader who saved the British economy and promoted the British international social position. In the Falklands War, she showed her excellent leadership about priority setting and decision making. Margaret Thatcher believed the preparation for unexpected things were significant and making the impossible happens is the art of leadership's art. Thatcherism was her representative characteristic of leadership. Until now, Thatcherism influence British economy and education deeply especially in economy and education.

\section{References}

[1] Barlow, P. (2002, 5 13). Margaret Thatcher's leadership in the Falklands conflict. London, United Kingdom: News International Trading Limited.

[2] Barnes, J. (2005, 01 10). Obituary: Sir Anthony Meyer Bt ; Conservative MP who challenged Margaret Thatcher for the leadership. London, United Kingdom: Independent Print Ltd.

[3] Daniel, H. (2011, 11 21). Margaret Thatcher. Human Events , 67. Washington, United States: Human Events Publishing, Inc.

[4] Essential Margaret Thatcher. (2013, 04 02). Retrieved from Margaret Thatcher Fundation: http://www.margaretthatcher.org/essential/biography.asp

[5] Gavin, C. (2009, 05 04). Cameron pays tribute to 'awe-inspiring' leadership of Margaret Thatcher. Belfast, United Kingdom: Independent News \& Media.

[6] Hutchinson, M. (2013, 04 07). BREAKINGVIEWS - Thatcher's economic revolution was not bloodless. Retrieved from Reuters: http://in.reuters.com/article/2013/04/08/breakingviews-thatcheridINDEE93709R20130408?type=economicNews

[7] Iorio, P. (2012, 01 13). Meeting Thatcher, Learning Leadership. Tampa Bay, United States.

[8] Miller, W. (1990, 11 15). Thatcher Faced with Leadership Challenge. Boston, United States: Globe Newspaper Company, Inc.

[9] Myers, E. M. (1994, 12). Lady Thatcher's leadership lessons. Washington, United States: American Society of Association Executives.

[10] Peter, J., \& Cullen. (1990, 05 18). Margaret Thatcher's Record. Jerusalem, Israel.

[11] T, B. W. (1987, 12 28). Margaret Thatcher's Model: Leadership, Not Popularity. San Francisco, Calif, United States: San Francisco Chronicle, a division of Hearst Communications Inc. 
The Thatcher years in statistics

Margaret Thatcher resigned as prime minister in 1990. Use this graphical guide to see

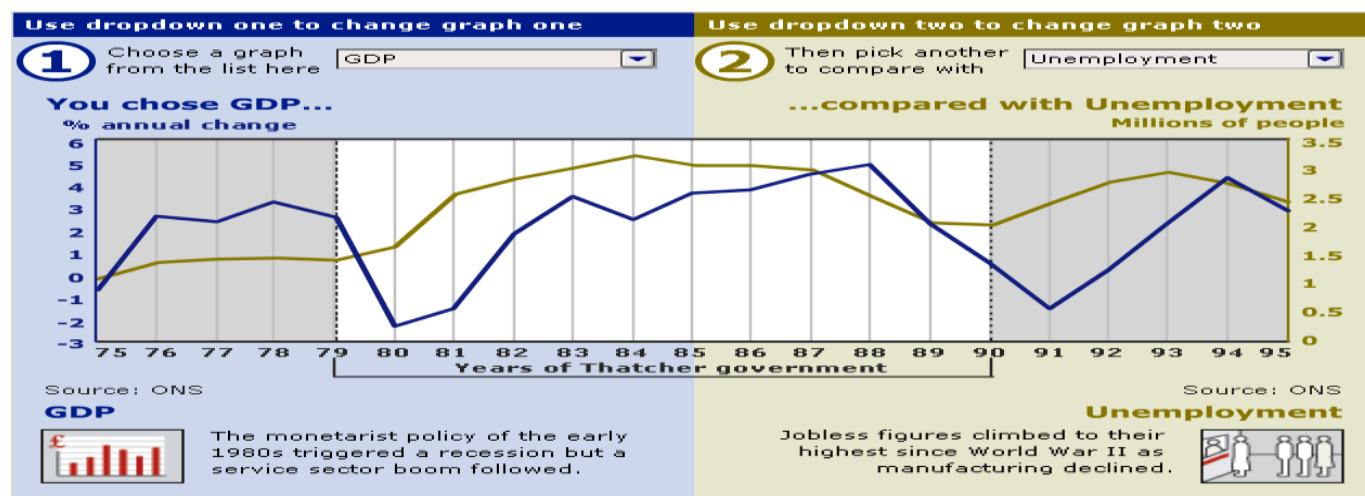

Figure 1. The tatcher years in statistics on unemployment

(http://news.bbc.co.uk/2/hi/in_depth/4447082.stm)

The Thatcher years in statistics

Margaret Thatcher resigned as prime minister in 1990 . Use this graphical guide to see Margare in Britain changed during her time in power.

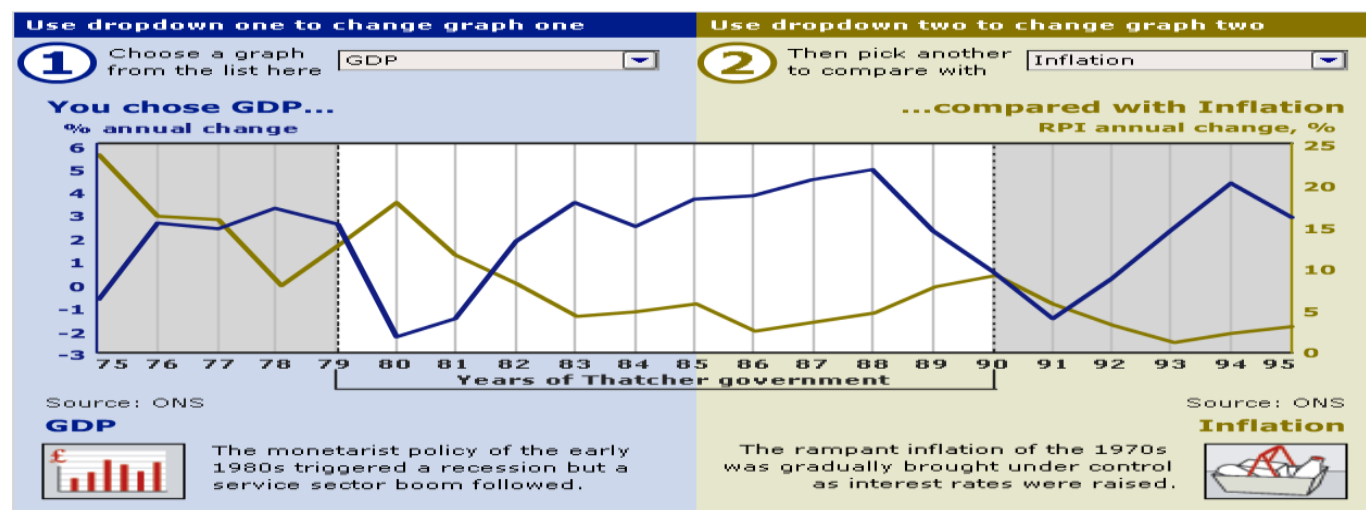

Figure 2. The tatcher years in statistics on inflation

(http://news.bbc.co.uk/2/hi/in_depth/4447082.stm)

The Thatcher years in statistics

Margaret Thatcher resigned as prime minister in 1990. Use this graphical guide to see how life in Britain changed during her time in power.

Use dropdown one to change graph one Use dropdown two to change graph two

(1) choose a graph $\begin{aligned} & \text { from the list here } \\ & \text { GDP }\end{aligned}$

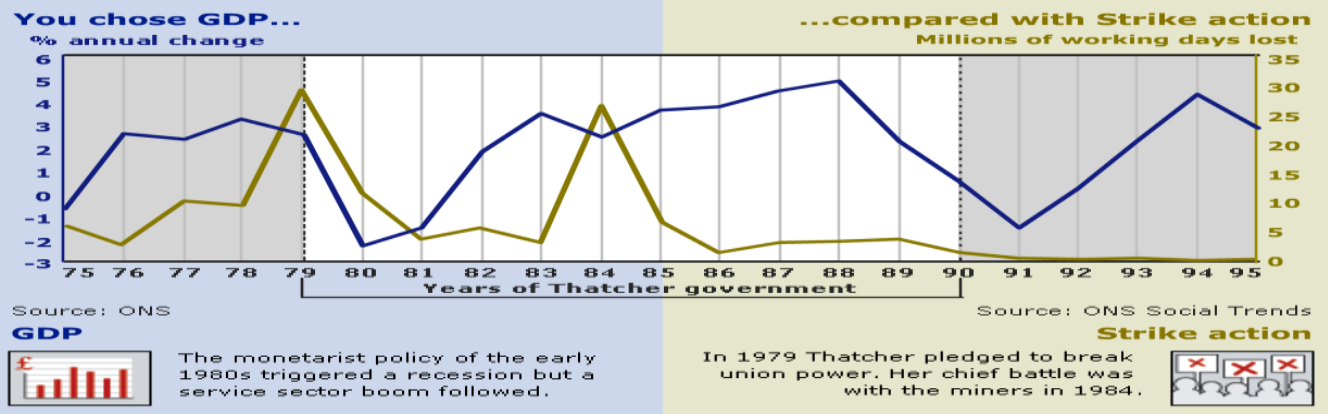

Figure 3. The tatcher years in statistics on strike action

(http://news.bbc.co.uk/2/hi/in_depth/4447082.stm) 